\title{
Use of Surfactant-Modified Zeolites and Clays for the Removal of Heavy Metals from Water
}

\author{
Martha E. Jiménez-Castañeda and Dora I. Medina * \\ Tecnologico de Monterrey, School of Engineering and Sciences, Atizapan de Zaragoza, \\ Estado de Mexico 52926, Mexico; mjcastaneda@itesm.mx \\ * Correspondence: dora.medina@cantab.net; Tel.: +52-55-5864-2448
}

Academic Editor: Andreas N. Angelakis

Received: 17 January 2017; Accepted: 22 March 2017; Published: 24 March 2017

\begin{abstract}
The presence of heavy metals in water for human use or consumption represents a major risk to human health. It is therefore important to find materials to remove or minimise the concentration of these pollutants. The adsorption process for the removal of heavy metals is favoured by the use of low-cost materials that exhibit a porous structure and a high cation exchange capacity, such as zeolites and clays. On the other hand, chemical treatments, e.g., using acids and bases, can modify the properties of these materials, but more recently the application of surfactants has also shown to be successful for broadening their metal affinity and allowing the removal of diverse organic and inorganic pollutants from water. This paper reviews the application of modified zeolites and clays for the removal of heavy metals from water.
\end{abstract}

Keywords: heavy metals; water treatment; surfactant-modified surfaces; zeolite; clay

\section{Introduction}

Proper multi-criteria of the ecological, environmental, and socio-economic impacts of contaminated sites are necessary for the decision support of sustainable strategies. Environmental impact assessment for economic development, for example, requires the analysis of qualitative and quantitative factors more than subjective decisions. Diverse simulation tools, such as the eutrophication modelling of coastal zones [1]; the Soil and Water Assessment Tool (SWAT) applied in the evaluation of ungauged watersheds [2] and the impact of agriculture on water quality [3]; and fuzzy methods [2] have been used for water quality evaluation and represent helpful options to monitor the fluid flow, water quality and interactions of water treatments in real time in order to support sustainable land and water management $[4,5]$.

Amongst the factors that affect the water quality, the discharge of heavy metals has exposed millions of people to their harmful effects, and it is one of the biggest environmental challenges faced by the world [6-9]. Heavy metals are persistent, bioaccumulative, and able to disrupt the metabolic functions and vital organs in humans and animals [10]. The biological function of heavy metals in trace concentrations is considered essential for plants and animals, but the chemical or physical transformation to which these metals are subjected will determine their toxicity and environmental behaviour [11]. Chromium (Cr) causes severe respiratory, cardiovascular, gastrointestinal, hematological, hepatic, renal, and neurological damage and has been suggested to be carcinogenic [12,13]. Arsenic (As) is a carcinogen present in water for human use that also produces harm to the cardiovascular, dermatologic, nervous, hepatobiliary, renal, gastrointestinal, and respiratory systems [14]. Mercury $(\mathrm{Hg})$ is a widespread genotoxic environmental pollutant that induces strong alterations in the body tissues, damages the pulmonary and kidney functions, and affects the immune and cardiovascular systems. Hg also hampers the development of the nervous system in fetuses and children [15]. Cadmium (Cd) is considered a human carcinogen with an impact 
on the respiratory system; its other effects include damage to the liver as well as the cardiovascular, immune, and reproductive systems $[12,16]$. Lead $(\mathrm{Pb})$ causes poor development of the brain and the nervous system, and it is particularly dangerous to fetuses and young children. Exposure to $\mathrm{Pb}$ damages the kidneys and the reproductive and nervous systems, and it accumulates in the teeth and bones [17]. Nickel's serious health effects may include chronic bronchitis, reduced lung function, and cancer of the lungs, and it also causes allergic reactions in humans [12,18]. Zinc (Zn) is an essential trace element that is considered to be relatively nontoxic to humans, but an overexposure can cause stomach cramps and irritation, vomiting, nausea, anemia, or even death [19].

Heavy metals are removed from aqueous solutions applying treatments such as osmosis [20,21], ion exchange [22], coagulation and precipitation [23]. Adsorption is extensively applied due to the flexibility of the process and, accordingly, many adsorbents with high adsorption capacity, including zeolites and clays, have been investigated. On the other hand, some zeolites and clays have some limited metal adsorption capacity and may require a chemical treatment before use in water or wastewater treatments. In recent years, the chemical modification of zeolites and clays has been explored with the purpose of increasing the heavy metal binding ability of these materials. This review seeks to show the results of the application of surfactant-modified zeolites and clays on the removal of heavy metals from water. The reader is encouraged to consult the references for detailed information about the modification processes

\section{Surfactants}

Surfactants are long-chain molecules that contain both hydrophilic and hydrophobic moieties; they are found in food [24] as well as in cosmetic [25] and industrial formulations [26]. Depending on their origin, surfactants are either biosurfactants or synthetic, and they can be classified as ionic and nonionic according to their hydrophilic moiety [27].

\subsection{Biosurfactants}

Biosurfactants are synthesised by microorganisms, plants, or animals, with a critical micelle concentration (CMC) ranging from 1 to $200 \mathrm{mg} / \mathrm{L}$ and a molecular mass ranging from 500 to $1500 \mathrm{Da}$ [28]. They are classified as glycolipids, lipopeptides, phospholipids, fatty acids, neutral lipids, and polymeric and particulate compounds [29]. Their hydrophilic moiety comprises carbohydrates, amino acids, cyclic peptides, phosphates, carboxylic acids, or alcohols, with the hydrophobic moiety made up of $\alpha-, \beta-$, and long-chain fatty acids [30,31]. Biosurfactants have been applied for the removal of copper, zinc, cadmium, and lead from soil and sediments [28,32].

\subsection{Synthetic Surfactants}

Synthetic surfactants can be either nonionic or ionic molecules. Nonionic surfactants cannot be ionised in aqueous solution; their hydrophilic moiety contains polyoxyethylene, polyoxypropylene, or polyol groups, and their hydrophobic moiety is comprised of fatty alcohols and saturated or unsaturated fatty acids. Compared to ionic surfactants, nonionic surfactants' lower CMC, higher degree of reduction in surface tension, and relatively constant properties in the presence of salts renders them more suitable to the remediation of soils, although the presence of clays and organic matter may influence their adsorption rate [30].

Ionic surfactants comprise the anionic, cationic, and zwitterionic or amphoteric surfactants [27]. Anionic surfactants usually have a sulfate, a sulfonate, or a carboxylate group as their hydrophilic moiety. They are found in pharmaceutical applications and detergent formulations and are used in soil remediation. Cationic surfactants have a hydrophilic part made up of quaternary ammonium groups. When cationic surfactants are used in soil remediation, they adsorb at negatively charged surfaces, such as silica [33] and clays [34], but they can also adsorb at cell membranes [30]. Dimeric (twin or gemini) surfactants contain more than one hydrophobic tail and hydrophilic head. These molecules usually have hydrophobic moieties comprised of paraffins, olefins, alkylbenzenes, alkylphenols, or 
alcohols [30]. They have low CMC values, a hard-water tolerance, superior wetting times, and low Krafft points, and they are much more surface active than conventional surfactants [35]. A special type of dimeric surfactant that contains both anionic and cationic surfactants and can adsorb onto both negatively and positively charged surfaces is called a zwitterionic surfactant. These behave either as cationic or anionic surfactants depending on the $\mathrm{pH}$ of the solution [30].

\subsection{Critical Micelle Concentration (CMC)}

In an aqueous solution at a certain concentration, surfactants form aggregates (the CMC). A micelle is a structure containing a hydrophobic interior and a hydrophilic exterior that behaves as large molecule [8]. In nonpolar media, the structure of the micelle is similar but reversed, with the hydrophilic heads comprising the interior region surrounded by an outer region containing the hydrophobic groups and nonpolar solvent [36]. At concentrations above the CMC, surfactants can form other structures (Figure 1). These structures are continuously forming and disintegrating [36].
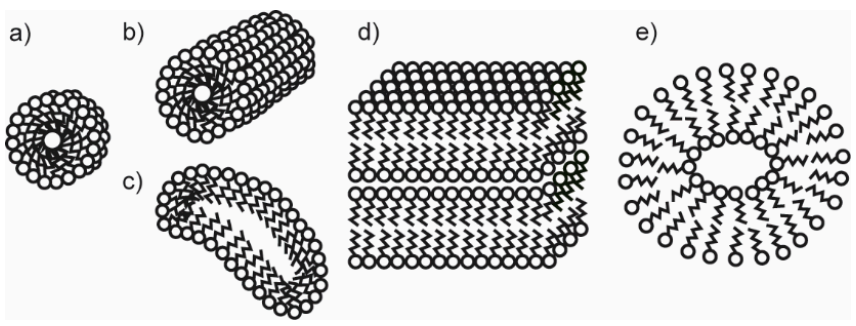

Figure 1. Surfactant aggregates: (a) spherical micelle; (b) cylindrical micelle; (c) worm-like micelle; (d) lamellar formation; and (e) vesicle.

\section{Treatments for Metal Removal}

Conventional processes include chemical precipitation [37,38], coagulation/flocculation [39-41], and ion exchange [22,42,43]. Adsorptive and membrane processes are widely used for the immobilisation and separation of metal species.

\subsection{Adsorption}

Adsorption has long been considered as a highly efficient water treatment method due to its low cost and ease of operation [12]. It involves the uptaking and immobilising of contaminants on an adsorbent and the related mechanisms, such as surface adsorption, partition, surface precipitation, and structural adsorption [7,44-46]. Low-cost adsorbents such as lignocellulosic materials [47-49], biomasses [50-52], agrowastes [44,53-55], and inorganic materials [41,56,57] are frequently used.

\subsection{Membrane Processes}

Owing to their efficiency, easy operation, and space-saving properties, membrane processes, including microfiltration, reverse osmosis, nanofiltration, and ultrafiltration, are promising technologies for the removal of metals from water [58-60]. Microfiltration removes contaminants using membranes with pore sizes in the range of 0.1 to $10 \mu \mathrm{m}$ and at pressures of 0.5 to 2 bar. In reverse osmosis, there is a semi-permeable membrane that moves ions from a region of high solute concentration to a region of low concentration by applying an operating pressure ranging from 20 to 100 bar. Nanofiltration can retain ions and low-molecular-weight organics of less than $1 \mathrm{~nm}$ at lower pressure (typically 7 to 30 bar). Ultrafiltration separates heavy metals in solution on the basis of the pore size of the membrane ( 5 to $20 \mathrm{~nm}$ ) and the molecular weight of the separating compounds, operating with a pressure of up to 10 bar $[7,12]$.

The application of surfactants to a metal-laden water below the CMC promotes the formation of insoluble surfactant-metal complexes [7]. At concentrations above the CMC, the metal ions bind 
into negatively charged micelles [61]. Both the metal-surfactant complexes and the metal-micelle aggregates can be further removed using micellar enhanced microfiltration (MEMF) or micellar enhanced ultrafiltration (MEUF; Figure 2). MEMF can remove multivalent metal ions from aqueous solutions using membranes manufactured from clays [62]. In MEUF, the surfactants are added at a concentration above their CMC to form large metal-surfactant micelles that are subsequently retained in an ultrafiltration membrane $[31,63]$. The MEUF increases the removal efficiency of metal ions using surfactants with an electric charge opposite to that of the targeted ions, but it has been suggested that the selectivity of this technique could be improved by using surfactants with the same charge as the metal ions $[8,63]$.

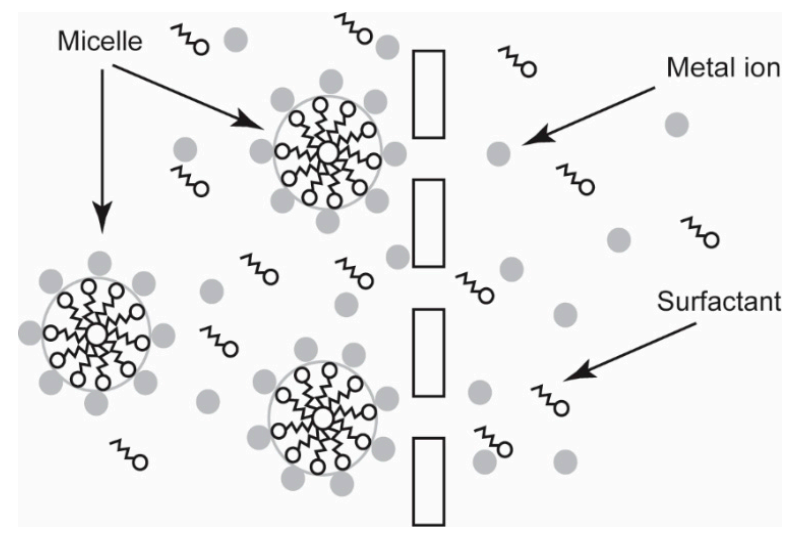

Figure 2. Representation of a surfactant-based separation process (MEUF) for the removal of metal ions [64].

\section{Surfactant-Modified Zeolites and Clays}

A variety of zeolites and clays play an important role in the environment and are frequently used as adsorbent materials for the removal of heavy metals. The sorption capacity of these materials can be enhanced when treated using acids and bases $[65,66]$. Owing to their amphiphilic nature, surfactants adsorb at diverse surfaces and interfaces in an oriented mode which will determine the hydrophilicity or hydrophobicity of the surface. Applied on zeolites and clays, surfactants have been used in the removal of diverse soil pollutants [11,67], remediation of non-aqueous phase liquids [68], pump-and-treat processes [69], and, more recently, to remove heavy metals from water.

The mechanisms for surfactant adsorption onto solid substrates are [36]: ion exchange, which involves the replacement of counter-ions adsorbed onto the substrate from the solution by similarly charged surfactant ions; ion pairing, which occurs via adsorbing surfactant ions from a solution onto the oppositely charged sites of the adsorbent that is unoccupied by counter-ions; hydrophobic bonding, which is based on the attraction between a hydrophobic group of an adsorbed molecule and a molecule present in the solution; adsorption by polarisation of $\pi$ electrons, which occurs when there is attraction between the electron-rich aromatic nuclei of a surfactant and the strongly positive sites of an adsorbent; and adsorption by dispersion forces, which is based on the London-van der Waals force between the surfactant and the adsorbent.

\subsection{Zeolites}

Zeolites are potential adsorbents used for water remediation because of their high ion exchange, adsorption molecular sieving capacity, and low cost. Natural and synthetic zeolites are aluminum silicates characterised by three-dimensional networks of tetrahedral units of silica and alumina, linked by the sharing of all oxygen atoms, with channels and/or interconnected voids. Zeolites display excellent an affinity for metal cations and adsorption and catalytic properties. In addition, cations of sodium, calcium, and potassium that are typically present in the channels of the zeolite structure 
can be replaced by other metal cations, including lead, cadmium, zinc, copper, nickel, iron, and manganese $[7,70,71]$.

By the addition of surfactants, the zeolite surface can be modified to enhance the anion exchange capacity and, to an extent, the potential to remove cations, anions, and organic compounds [70,72-75]. Two control factors for surfactant sorption on zeolites are the initial concentration of the surfactant and the external cation exchange capacity (ECEC) of the zeolite. The surfactant concentration determines the behaviour of the surfactant in solution, while the ECEC characterises the exchange capacity of the mineral surface.

\subsection{Clays}

Clays are hydrous aluminum silicates characterised by a structure composed of a tetrahedral sheet of silicates linked to an octahedral sheet of aluminates. They can adsorb cations, anions, and neutral metal species from water bodies $[9,75,76]$.

The metal adsorption in clays is driven by either selective or non-selective mechanisms. In selective sorption, clays adsorb ions through exchangeable cations and electrostatically bound counter-ions in the diffusion layer, which is formed due to the surface charge [77]. In non-selective or exchangeable sorption, the amount of cations sorbed is proportional to their relative concentration in the solution [78], and this occurs in a large range of $\mathrm{pH}$ values around the zero point of charge (ZPC) of the minerals whenever $\mathrm{pH}>\mathrm{ZPC}, \mathrm{pH}=\mathrm{ZPC}$ or $\mathrm{pH}<\mathrm{ZPC}$ [77]. When clays are used in acid media, the metal adsorption rate increases as the $\mathrm{pH}$ increases. At near-neutral to alkaline conditions, the metal ions can be removed from the aqueous phase, presumably as hydroxyl species [12].

The application of cationic surfactants increases both the anionic adsorptive capacity and the cation affinity of clays, although the modification is limited to their external surfaces $[76,79,80]$. Surfactant-modified clays can be applied for the removal of heavy metal from water through ion exchange, precipitation-dissolution, and counter-ion binding mechanisms [8,81]. They can also be used to sorb metal cations and form complexes when their surfaces have negatively charged sites or there is a replacement of weakly held counter-ions in the solution [9].

\section{Use of Surfactant-Modified Zeolites and Clays}

A general model of the modification of a solid surface via the sorption of an ionic surfactant is shown in Figure 3. When low surfactant concentrations are applied onto the zeolite surface, surfactant molecules exist as monomers that are exchanged with the exchangeable cations of the zeolite until a hemimicelle (or monolayer) of surfactant molecules is established at its external surface. At concentrations above the $\mathrm{CMC}$, the surfactant molecules will form an admicelle (or bilayer) attached to the external surface of the zeolite $[82,83]$.

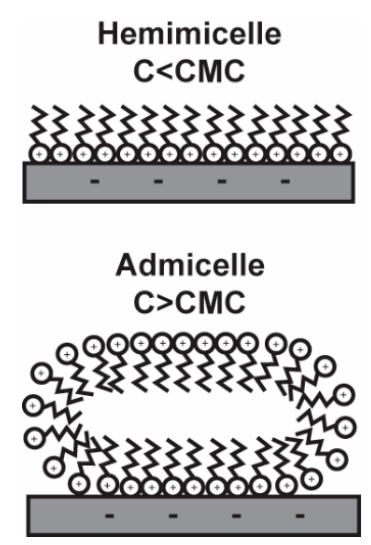

Figure 3. Surfactant modification of a solid surface forming a positive monolayer (hemimicelle) and a positive bilayer (admicelle) on a solid surface [84]. 
The application to zeolites and clays of cationic surfactants with long alkyl chains, quaternary ammonium groups, and a counter-anion changes their external charge from negative to positive, mainly by cationic exchange and hydrophobic interactions. Chutia et al. [85] indicated that the new positive surface can be balanced by anionic counter-ions, which increase the affinity of zeolites to sorb anionic contaminants $[72,80,83,86]$. Li et al. [87] suggested that the use of cationic surfactants with chloride $\left(\mathrm{Cl}^{-}\right)$and bromide $\left(\mathrm{Br}^{-}\right)$counter-ions in the treatment of a zeolite originates complete bilayer formations, whereas surfactants containing the hydrogen sulfate ion $\left(\mathrm{HSO}_{4}\right)$ cause less than full bilayer formations.

\subsection{Surfactant-Modified Zeolites}

Zeolites have been widely used for their adsorptive properties and low cost. However, zeolites possess a net negative structural charge resulting from the isomorphic substitution of cations in the crystal lattice that gives zeolites little or no affinity for anions. The modification of clinoptilolite using hexadecyl trimethyl ammonium bromide (HDTMA-Br) and octadecyl trimethyl ammonium bromide (ODTMA-Br) surfactants increased its anionic sorption capacity, allowing for the removal of chromates and iodide from aqueous solutions [88]. Both surfactants altered the zeolite surface, although the ODTMA-clinoptilolite exhibited greater chromate and iodide sorption capacity (2.27 and $4.02 \mathrm{mg} / \mathrm{g}$, respectively) than the HDTMA-clinoptilolite ( 2.18 and $3.37 \mathrm{mg} / \mathrm{g}$, respectively). Leyva-Ramos et al. [83] indicated that HDTMA-clinoptilolite can sorb up to 22 times more $\mathrm{Cr}(\mathrm{VI})$ than an untreated zeolite. Other contaminants removed using HDTMA-Br clinoptilolite are selenates and sulfates [84].

Mordenite showed a considerable affinity for $\mathrm{Cr}(\mathrm{VI})$ species after treatment with $\mathrm{HDTMA}-\mathrm{HSO}_{4}$ and ethyl hexadecyl dimethyl ammonium (EHDDMA). The unmodified zeolite had no affinity for such

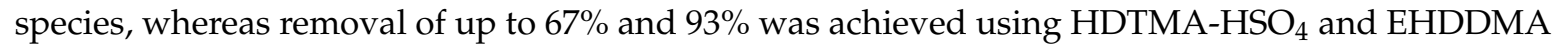
mordenites, respectively [89]. The modification of mordenite and clinoptilolite using HDTMA-Br notably increases their $\mathrm{As}(\mathrm{V})$ removal efficiency from $52 \%$ and $20 \%$ up to $92 \%$ and $86 \%$, respectively [85]. Natural clinoptilolite and chabazite, which have no affinity for $\mathrm{Cr}(\mathrm{VI})$, removed up to 1.8 and $2.0 \mathrm{mg} / \mathrm{g}$, respectively, after modification with hexadecyl pyridinium bromide (HDPB). The highest adsorption capacity for modified clinoptilolite occurs at a $\mathrm{pH}$ range of 3.0 to 5.0; for modified chabazite, it occurs at a $\mathrm{pH}$ range of 3.0 to 11.0 [90]. The use of HDTMA-Br also increases the $\mathrm{Cr}(\mathrm{VI})$ adsorption capacity of the zeolites, especially for clinoptilolite in a $\mathrm{pH}$ range of 3.0 to 11.0 [91]. Cationic surfactants can also enhance the metal affinity of synthesised zeolites; for instance, HDTMA-Br laumontite was successfully tested for the removal of chromate, molybdate, and tungstate [72]. Yusof and Malek [92] reported the adsorption of $\mathrm{Cr}(\mathrm{VI})$ and $\mathrm{As}(\mathrm{V})$ using a zeolite $\mathrm{Y}$ synthesised from rice husk ash that had been modified using HDTMA-Br. The unmodified zeolite $Y$ has little or no affinity for these metal species.

Comparing the application of the cationic surfactant Uniquat QAC-50 and the amphoteric surfactant Miranol-C2MSF for the removal of heavy metals from mine waters, it was found that the amphoteric-treated zeolite adsorbed up to $85 \%$ of the initial metal concentration, with a preference for chromates. However, such efficiency was lower than that observed using the cationic surfactant, especially for copper $(\mathrm{Cu})$ and iron $(\mathrm{Fe})[93]$. $\mathrm{Cr}(\mathrm{VI})$ has been successfully removed using natrolite modified with the gemini surfactant $N, N, N, N^{\prime}, N^{\prime}, N^{\prime}$-hexamethyl-1,9-nonanediammonium dibromide (HMNA- $\mathrm{Br}_{2}$ ), with an efficiency ranging from $70 \%$ to $90 \%$, depending on the $\mathrm{pH}$ of the solution [94].

\subsection{Surfactant-Modified Clays}

The application of a cationic surfactant on clays causes the change of the clay surface from hydrophilic to hydrophobic and from negatively to positively charged, due to the sorption of the molecule onto its external surface and into the interlayer spacing. Therefore, the surfactant-modified clay exhibits an anion exchange capacity [95]. Quaternary ammonium cations are the most frequently used surfactants for preparing clays, with an excellent hydrophobicity and great efficiency for metals and organic contaminants recovery, although the mechanisms for surfactant adsorption on the clay 
surface are not clear. Krishna et al. [96] indicated that the application of HDTMA-Br on montmorillonite constricts the pore channels of the clay due to the attachment of the surfactant moieties to its surface. More recently, $\mathrm{Li}$ and Gallus [80] indicated that when a cationic surfactant is applied on kaolinite, the surfactant sorption is limited to the external surfaces, although the surfactant molecules sorb on the surfaces as well as in interlayer spaces when using smectites. The metal speciation also determines the removal mechanisms acting on a surfactant-modified clay. In the case of the sorption of arsenate and arsenite on HDTMA-kaolinite, anion exchange is considered the dominant mechanism for arsenate sorption, whereas surface complexation could also be accounted for arsenite sorption [97].

The modification of kaolinite using cationic surfactants changes the negative basal surface charge of the clay and enhances the adsorptive capacity for contaminants; for example, HDTMA-Cl kaolinites are able to adsorb up to 10 times more $\mathrm{Cr}(\mathrm{VI})$ than the natural form by significantly increasing both the specific surface area and the CEC of the clay [79]. Sodium dodecyl sulfate (SDS) montmorillonites can remove copper, mercury, and zinc from water [9,81]. HDTMA-Br montmorillonites achieved a high $\mathrm{Cr}(\mathrm{VI})$ affinity at a low $\mathrm{pH}$ [96], and a cetyl pyridinium bromide (CPB) montmorillonite removed $\mathrm{Cr}(\mathrm{VI})$ over a $\mathrm{pH}$ range from 3.0 to 6.0 with an approximated efficiency of $98 \%$ [98]. Palygorskite and sepiolite modified with HDTMA-Br showed a $\mathrm{Cr}(\mathrm{VI})$ sorption capacity of 42 and $34 \mathrm{mmol} / \mathrm{kg}$ for HDTMA-palygorskite and HDTMA-sepiolite, respectively. Using dodecyl trimethyl ammonium bromide (DDTMA-Br) in the treatment of palygorskite resulted in a chromate sorption capacity of $17 \mathrm{mmol} / \mathrm{kg}$ [99]. Cetyl pyridinium bromide (CPB)-modified bentonite adsorbed up to 0.7 and $1.4 \mathrm{mmol} / \mathrm{g}$ of $\mathrm{Cr}(\mathrm{VI})$ and $\mathrm{Mo}(\mathrm{VI})$, respectively, from water [100].

Surfactant-modified clays also allow for the simultaneous removal of organic contaminants and heavy metals. Montmorillonite modified with carboxy decyl triethyl ammonium bromide (CDTEA-Br) showed promise for the adsorption of both $\mathrm{Pb}(\mathrm{II})$ and chlorobenzene [101]. Kaolin modified with cetyl trimethyl ammonium (CTAB) removes both $\mathrm{Cu}(\mathrm{II})$ and organic pollutants, such as o-xylene and phenol [95]. The modification notably increases the adsorption capacity of the natural kaolin (19.2 and $5.1 \mathrm{mg} / \mathrm{g}$ for $\mathrm{Cu}(\mathrm{II})$ and phenol, respectively) up to $38.5 \mathrm{mg} / \mathrm{g}$ for $\mathrm{Cu}(\mathrm{II}), 91.5 \mathrm{mg} / \mathrm{g}$ for phenol, and $51.8 \mathrm{mg} / \mathrm{g}$ for o-xylene. Using the zwitterionic surfactant hexadecyldimethyl (3-sulphonatopropyl) ammonium on montmorillonite allows the removal of $\mathrm{Cu}$ (II) and phenol; however, the comparison with HDTMA-Br montmorillonite suggests that the adsorption capacity of the clay, both for organics and metals, is slightly higher using a cationic surfactant [81]. However, the application of quaternary ammonium cations on montmorillonites decreased the metal adsorption capacity of the clay since the interlayer quaternary ammonium cations are not readily exchangeable or the hydrophobic interlayer environment of the montmorillonite restrains the adsorption toward the hydrated metal cation [81].

Mixtures of surfactants have a more complex behaviour than a single surfactant. They have unique properties with industrial applications, but these properties will change depending on the surfactants used and the concentration in which they are present [102]. The mixtures can be unstable and precipitate, although several studies indicate that combination is possible. Mixed surfactants applied on zeolites and clay surfaces could be considered as pseudo-zwitterionic molecules, but this area requires more research for diverse contaminants [103-108].

\section{Conclusions}

Adsorption is still an important treatment for water contaminated with heavy metals, and therefore the research into new materials with better adsorption properties is relevant for increasing the efficiency of the process. Zeolites and clays are low-cost materials broadly applied in adsorption processes, hence the research on the development of these materials requires continued investigation and testing, for example regarding the application of surfactants to promote the sorption of metal anions and organic pollutants while retaining the sorption capacity for metal cations. Moreover, the consideration of such promising adsorbents for water and wastewater treatments, combined with the monitoring and modelling of water quality, offers an integral solution for the sustainable management of water resources in order to determine the level of contaminants and the decisions required. Further 
research on these topics is needed to better understand the mechanisms for metal removal using modified materials and the impact on the environment.

Acknowledgments: The authors gratefully acknowledge the financial support of the National Council of Science and Technology of Mexico (CONACyT).

Author Contributions: M.E.J.-C. and D.I.M. wrote the paper, conceptualised the study; D.I.M. led the work.

Conflicts of Interest: The authors declare no conflict of interest.

\section{References}

1. Zhao, M.Y.; Cheng, C.T.; Chau, K.W.; Li, G. Multiple criteria data envelopment analysis for full ranking units associated to environment impact assessment. Int. J. Environ. Pollut. 2006, 28, 448-464. [CrossRef]

2. Wang, W.C.; Xu, D.M.; Chau, K.W.; Lei, G.J. Assessment of river water quality based on theory of variable fuzzy sets and fuzzy binary comparison method. Water Resour. Manag. 2014, 28, 4183-4200. [CrossRef]

3. Rajib, M.A.; Ahiablame, L.; Paul, M. Modeling the effects of future land use change on water quality under multiple scenarios: A case study of low-input agriculture with hay/pasture production. Sustain. Water Qual. Ecol. 2016, 8, 50-66. [CrossRef]

4. Chau, K.W. Integrated water quality management in Tolo Harbour, Hong Kong: A case study. J. Clean. Product. 2007, 15, 1568-1572. [CrossRef]

5. Gwenzi, W.; Dunjana, N.; Pisa, C.; Tauro, T.; Nyamadzawo, G. Water quality and public health risks associated with roof rainwater harvesting systems for potable supply: Review and perspectives. Sustain. Water Qual. Ecol. 2015, 6, 107-118. [CrossRef]

6. Harwell, J.H.; Sabatini, D.A.; Knox, R.C. Surfactants for ground water remediation. Colloids Surf. A Physicochem. Eng. Asp. 1999, 151, 255-268. [CrossRef]

7. Barakat, M.A. New trends in removing heavy metals from industrial wastewater. Arab. J. Chem. 2011, 4, 361-377. [CrossRef]

8. Nivas, B.T.; Sabatini, D.A.; Shiau, B.-J.; Harwell, J.H. Surfactant enhanced remediation of subsurface chromium contamination. Water Res. 1996, 30, 511-520. [CrossRef]

9. Lin, S.-H.; Juang, R.-S. Heavy metal removal from water by sorption using surfactant-modified montmorillonite. J. Hazard. Mater. 2002, 92, 315-326. [CrossRef]

10. Tchounwou, P.B.; Yedjou, C.G.; Patlolla, A.K.; Sutton, D.J. Heavy metals toxicity and the environment. EXS 2012, 101, 133-164. [PubMed]

11. Mulligan, C.N.; Yong, R.N.; Gibbs, B.F. Heavy metal removal from sediments by biosurfactants. J. Hazard. Mater. 2001, 85, 111-125. [CrossRef]

12. Fu, F.; Wang, Q. Removal of heavy metal ions from wastewaters: A review. J. Environ. Manag. 2011, 92, 407-418. [CrossRef] [PubMed]

13. Léonard, A.; Lauwerys, R.R. Carcinogenicity and mutagenicity of chromium. Mutat. Res. Rev. Genet. Toxicol. 1980, 76, 227-239. [CrossRef]

14. Berg, M.; Tran, H.C.; Nguyen, T.C.; Pham, H.V.; Schertenleib, R.; Giger, W. Arsenic contamination of groundwater and drinking water in vietnam: A human health threat. Environ. Sci. Technol. 2001, 35, 2621-2626. [CrossRef] [PubMed]

15. Zahir, F.; Rizwi, S.J.; Haq, S.K.; Khan, R.H. Low dose mercury toxicity and human health. Environ. Toxicol. Pharmacol. 2005, 20, 351-360. [CrossRef] [PubMed]

16. Waalkes, M.P. Cadmium carcinogenesis in review. J. Inorg. Biochem. 2000, 79, 241-244. [CrossRef]

17. Goyer, R.A. Lead toxicity: Current concerns. Environ. Health Perspect. 1993, 100, 177-187. [CrossRef] [PubMed]

18. Grandjean, P. Human exposure to nickel. IARC Sci. Publ. 1983, 469-485.

19. Plum, L.M.; Rink, L.; Haase, H. The essential toxin: Impact of zinc on human health. Int. J. Environ. Res. Public Health 2010, 7, 1342-1365. [CrossRef] [PubMed]

20. Cui, Y.; Ge, Q.; Liu, X.Y.; Chung, T.S. Novel forward osmosis process to effectively remove heavy metal ions. J. Membr. Sci. 2014, 467, 188-194. [CrossRef]

21. Qdais, H.A.; Moussa, H. Removal of heavy metals from wastewater by membrane processes: A comparative study. Desalination 2004, 164, 105-110. [CrossRef] 
22. Dabrowski, A.; Hubicki, Z.; Podkościelny, P.; Robens, E. Selective removal of the heavy metal ions from waters and industrial wastewaters by ion-exchange method. Chemosphere 2004, 56, 91-106. [CrossRef] [PubMed]

23. Charerntanyarak, L. Heavy metals removal by chemical coagulation and precipitation. Water Sci. Technol. 1999, 39, 135-138. [CrossRef]

24. Kralova, I.; Sjöblom, J. Surfactants used in food industry: A review. J. Dispers. Sci. Technol. 2009, 30, 1363-1383. [CrossRef]

25. Lourith, N.; Kanlayavattanakul, M. Natural surfactants used in cosmetics: Glycolipids. Int. J. Cosmet. Sci. 2009, 31, 255-261. [CrossRef] [PubMed]

26. Scheibel, J.J. The evolution of anionic surfactant technology to meet the requirements of the laundry detergent industry. J. Surf. Deterg. 2004, 7, 319-328. [CrossRef]

27. Urum, K.; Pekdemir, T. Evaluation of biosurfactants for crude oil contaminated soil washing. Chemosphere 2004, 57, 1139-1150. [CrossRef] [PubMed]

28. Mulligan, C.N.; Yong, R.N.; Gibbs, B.F.; James, S.; Bennett, H.P.J. Metal removal from contaminated soil and sediments by the biosurfactant surfactin. Environ. Sci. Technol. 1999, 33, 3812-3820. [CrossRef]

29. Desai, J.D.; Banat, I.M. Microbial production of surfactants and their commercial potential. Microbiol. Mol. Biol. Rev. 1997, 61, 47-64. [PubMed]

30. Paria, S. Surfactant-enhanced remediation of organic contaminated soil and water. Adv. Colloid Interface Sci. 2008, 138, 24-58. [CrossRef] [PubMed]

31. Mulligan, C.N. Environmental applications for biosurfactants. Environ. Pollut. 2005, 133, 183-198. [CrossRef] [PubMed]

32. Juwarkar, A.A.; Nair, A.; Dubey, K.V.; Singh, S.K.; Devotta, S. Biosurfactant technology for remediation of cadmium and lead contaminated soils. Chemosphere 2007, 68, 1996-2002. [CrossRef] [PubMed]

33. Goloub, T.P.; Koopal, L.K.; Bijsterbosch, B.H.; Sidorova, M.P. Adsorption of cationic surfactants on silica. Surface charge effects. Langmuir 1996, 12, 3188-3194. [CrossRef]

34. Xu, S.; Boyd, S.A. Cationic surfactant adsorption by swelling and nonswelling layer silicates. Langmuir 1995, 11, 2508-2514. [CrossRef]

35. Schramm, L.L.; Stasiuk, E.N.; Marangoni, D.G. Surfactants and their applications. Annu. Rep. Sect. C Phys. Chem. 2003, 99, 3-48. [CrossRef]

36. Rosen, M.J. Surfactants and Interfacial Phenomena; John Wiley \& Sons, Inc.: Hoboken, NJ, USA, 2004.

37. Peligro, F.R.; Pavlovic, I.; Rojas, R.; Barriga, C. Removal of heavy metals from simulated wastewater by in situ formation of layered double hydroxides. Chem. Eng. J. 2016, 306, 1035-1040. [CrossRef]

38. Fu, F.; Xie, L.; Tang, B.; Wang, Q.; Jiang, S. Application of a novel strategy-Advanced Fenton-chemical precipitation to the treatment of strong stability chelated heavy metal containing wastewater. Chem. Eng. J. 2012, 189-190, 283-287. [CrossRef]

39. Meunier, N.; Drogui, P.; Montané, C.; Hausler, R.; Mercier, G.; Blais, J.-F. Comparison between electrocoagulation and chemical precipitation for metals removal from acidic soil leachate. J. Hazard. Mater. 2006, 137, 581-590. [CrossRef] [PubMed]

40. El Samrani, A.G.; Lartiges, B.S.; Villiéras, F. Chemical coagulation of combined sewer overflow: Heavy metal removal and treatment optimization. Water Res. 2008, 42, 951-960. [CrossRef] [PubMed]

41. Assaad, E.; Azzouz, A.; Nistor, D.; Ursu, A.V.; Sajin, T.; Miron, D.N.; Monette, F.; Niquette, P.; Hausler, R. Metal removal through synergic coagulation-flocculation using an optimized chitosan-montmorillonite system. Appl. Clay Sci. 2007, 37, 258-274. [CrossRef]

42. Rengaraj, S.; Yeon, K.-H.; Moon, S.-H. Removal of chromium from water and wastewater by ion exchange resins. J. Hazard. Mater. 2001, 87, 273-287. [CrossRef]

43. Chiarle, S.; Ratto, M.; Rovatti, M. Mercury removal from water by ion exchange resins adsorption. Water Res. 2000, 34, 2971-2978. [CrossRef]

44. Annadurai, G.; Juang, R.S.; Lee, D.J. Adsorption of heavy metals from water using banana and orange peels. Water Sci. Technol. 2003, 47, 185-190.

45. Kadirvelu, K.; Thamaraiselvi, K.; Namasivayam, C. Removal of heavy metals from industrial wastewaters by adsorption onto activated carbon prepared from an agricultural solid waste. Bioresour. Technol. 2001, 76, 63-65. [CrossRef] 
46. Zhu, R.; Chen, Q.; Zhou, Q.; Xi, Y.; Zhu, J.; He, H. Adsorbents based on montmorillonite for contaminant removal from water: A review. Appl. Clay Sci. 2016, 123, 239-258. [CrossRef]

47. Miretzky, P.; Cirelli, A.F. Cr(VI) and $\mathrm{Cr}(\mathrm{III})$ removal from aqueous solution by raw and modified lignocellulosic materials: A review. J. Hazard. Mater. 2010, 180, 1-19. [CrossRef] [PubMed]

48. Basso, M.C.; Cerrella, E.G.; Cukierman, A.L. Lignocellulosic materials as potential biosorbents of trace toxic metals from wastewater. Ind. Eng. Chem. Res. 2002, 41, 3580-3585. [CrossRef]

49. Lee, B.-G.; Rowell, R.M. Removal of heavy metal ions from aqueous solutions using lignocellulosic fibers. J. Nat. Fibers 2004, 1, 97-108. [CrossRef]

50. Yan, G.; Viraraghavan, T. Heavy metal removal in a biosorption column by immobilized M. Rouxii biomass. Bioresour. Technol. 2001, 78, 243-249. [CrossRef]

51. Mallick, N. Biotechnological potential of immobilized algae for wastewater N, P and metal removal: A review. Biometals 2002, 15, 377-390. [CrossRef] [PubMed]

52. Ahluwalia, S.S.; Goyal, D. Microbial and plant derived biomass for removal of heavy metals from wastewater. Bioresour. Technol. 2007, 98, 2243-2257. [CrossRef] [PubMed]

53. Demirbas, A. Heavy metal adsorption onto agro-based waste materials: A review. J. Hazard. Mater. 2008, 157, 220-229. [CrossRef] [PubMed]

54. Sud, D.; Mahajan, G.; Kaur, M.P. Agricultural waste material as potential adsorbent for sequestering heavy metal ions from aqueous solutions-A review. Bioresour. Technol. 2008, 99, 6017-6027. [CrossRef] [PubMed]

55. Saeed, A.; Iqbal, M.; Akhtar, M.W. Removal and recovery of lead(II) from single and multimetal (Cd, Cu, $\mathrm{Ni}, \mathrm{Zn}$ ) solutions by crop milling waste (black gram husk). J. Hazard. Mater. 2005, 117, 65-73. [CrossRef] [PubMed]

56. Mavrov, V.; Erwe, T.; Blöcher, C.; Chmiel, H. Study of new integrated processes combining adsorption, membrane separation and flotation for heavy metal removal from wastewater. Desalination 2003, 157, 97-104. [CrossRef]

57. Blanchard, G.; Maunaye, M.; Martin, G. Removal of heavy metals from waters by means of natural zeolites. Water Res. 1984, 18, 1501-1507. [CrossRef]

58. Juang, R.-S.; Shiau, R.-C. Metal removal from aqueous solutions using chitosan-enhanced membrane filtration. J. Membr. Sci. 2000, 165, 159-167. [CrossRef]

59. Blöcher, C.; Dorda, J.; Mavrov, V.; Chmiel, H.; Lazaridis, N.K.; Matis, K.A. Hybrid flotation-membrane filtration process for the removal of heavy metal ions from wastewater. Water Res. 2003, 37, 4018-4026. [CrossRef]

60. Chaufer, B.; Deratani, A. Removal of metal ions by complexation-ultrafiltration using water-soluble macromolecules: Perspective of application to wastewater treatment. Nucl. Chem. Waste Manag. 1988, 8, 175-187. [CrossRef]

61. Hąc-Wydro, K.; Pałasińska, I.; Miśkowiec, P. The comparative studies on the ability of anionic surfactants to bind lead(II) ions. J. Mol. Liq. 2016, 219, 1071-1077. [CrossRef]

62. Puasa, S.W.; Ruzitah, M.S.; Sharifah, A.S.A.K. Competitive binding interaction between anionic reactive dyes and cleavable surfactant micelles in micellar-enhanced microfiltration. Procedia Eng. 2016, 148, 516-523. [CrossRef]

63. Juang, R.-S.; Xu, Y.-Y.; Chen, C.-L. Separation and removal of metal ions from dilute solutions using micellar-enhanced ultrafiltration. J. Membr. Sci. 2003, 218, 257-267. [CrossRef]

64. Samper, E.; Rodríguez, M.; De la Rubia, M.A.; Prats, D. Removal of metal ions at low concentration by micellar-enhanced ultrafiltration (MEUF) using sodium dodecyl sulfate (SDS) and linear alkylbenzene sulfonate (LAS). Sep. Purif. Technol. 2009, 65, 337-342. [CrossRef]

65. Lothenbach, B.; Furrer, G.; Schulin, R. Immobilization of heavy metals by polynuclear aluminium and montmorillonite compounds. Environ. Sci. Technol. 1997, 31, 1452-1462. [CrossRef]

66. Ruiz, R.; Blanco, C.; Pesquera, C.; González, F.; Benito, I.; López, J.L. Zeolitization of a bentonite and its application to the removal of ammonium ion from waste water. Appl. Clay Sci. 1997, 12, 73-83. [CrossRef]

67. Torabian, A.; Kazemian, H.; Seifi, L.; Bidhendi, G.N.; Azimi, A.A.; Ghadiri, S.K. Removal of petroleum aromatic hydrocarbons by surfactant-modified natural zeolite: The effect of surfactant. CLEAN Soil Air Water 2010, 38, 77-83. [CrossRef]

68. Fortin, J.; Jury, W.A.; Anderson, M.A. Enhanced removal of trapped non-aqueous phase liquids from saturated soil using surfactant solutions. J. Contam. Hydrol. 1997, 24, 247-267. [CrossRef] 
69. Mulligan, C.N.; Yong, R.N.; Gibbs, B.F. Surfactant-enhanced remediation of contaminated soil: A review. Eng. Geol. 2001, 60, 371-380. [CrossRef]

70. Apreutesei, R.E.; Catrinescu, C.; Teodosiu, C. Surfactant-modified natural zeolites for environmental applications in water purification. Environ. Eng. Manag. J. 2008, 7, 149-161.

71. Dursun, S.; Pala, A. Lead pollution removal from water using a natural zeolite. J. Int. Environ. Appl. Sci. 2007, 7, 11-19.

72. Gupta, P.; Khanday, W.A.; Majid, S.A.; Kushwa, V.; Tomar, S.S.; Tomar, R. Study of sorption of metal oxoanions from waste water on surfactant modified analog of laumontite. J. Environ. Chem. Eng. 2013, 1, 510-515. [CrossRef]

73. Misaelides, P. Application of natural zeolites in environmental remediation: A short review. Microporous Mesoporous Mater. 2011, 144, 15-18. [CrossRef]

74. Oliveira, C.; Rubio, J. New basis for adsorption of ionic pollutants onto modified zeolites. Miner. Eng. 2007, 20, 552-558. [CrossRef]

75. Jiang, J.-Q.; Ashekuzzaman, S.M. Development of novel inorganic adsorbent for water treatment. Curr. Opin. Chem. Eng. 2012, 1, 191-199. [CrossRef]

76. Adebowale, K.O.; Unuabonah, I.E.; Olu-Owolabi, B.I. The effect of some operating variables on the adsorption of lead and cadmium ions on kaolinite clay. J. Hazard. Mater. 2006, 134, 130-139. [CrossRef] [PubMed]

77. He, H.; Guo, J.; Xie, X.; Peng, J. Experimental study of the selective adsorption of heavy metals onto clay minerals. Chin. J. Geochem. 2000, 19, 105-109. [CrossRef]

78. Sawhney, B.L. Selective sorption and fixation of cations by clay minerals: A review. Clays Clay Miner. 1972, 20. [CrossRef]

79. Jin, X.; Jiang, M.; Du, J.; Chen, Z. Removal of $\mathrm{Cr}(\mathrm{VI})$ from aqueous solution by surfactant-modified kaolinite. J. Ind. Eng. Chem. 2014, 20, 3025-3032. [CrossRef]

80. Li, Z.; Gallus, L. Surface configuration of sorbed hexadecyltrimethylammonium on kaolinite as indicated by surfactant and counterion sorption, cation desorption, and FTIR. Colloids Surf. A Physicochem. Eng. Asp. 2005, 264, 61-67. [CrossRef]

81. Ma, L.; Chen, Q.; Zhu, J.; Xi, Y.; He, H.; Zhu, R.; Tao, Q.; Ayoko, G.A. Adsorption of phenol and Cu(II) onto cationic and zwitterionic surfactant modified montmorillonite in single and binary systems. Chem. Eng. J. 2016, 283, 880-888. [CrossRef]

82. Dionisiou, N.S.; Matsi, T. Natural and surfactant-modified zeolite for the removal of pollutants (mainly inorganic) from natural waters and wastewaters. In Environmental Materials and Waste; Academic Press: Cambridge, MA, USA, 2016; pp. 591-606.

83. Leyva-Ramos, R.; Jacobo-Azuara, A.; Diaz-Flores, P.E.; Guerrero-Coronado, R.M.; Mendoza-Barron, J.; Berber-Mendoza, M.S. Adsorption of chromium(VI) from an aqueous solution on a surfactant-modified zeolite. Colloids Surf. A Physicochem. Eng. Asp. 2008, 330, 35-41. [CrossRef]

84. Haggerty, G.M.; Bowman, R.S. Sorption of chromate and other inorganic anions by organo-zeolite. Environ. Sci. Technol. 1994, 28, 452-458. [CrossRef] [PubMed]

85. Chutia, P.; Kato, S.; Kojima, T.; Satokawa, S. Adsorption of As(VI) on surfactant-modified natural zeolites. J. Hazard. Mater. 2009, 162, 204-211. [CrossRef] [PubMed]

86. Faghihian, H.; Bowman, R.S. Adsorption of chromate by clinoptilolite exchanged with various metal cations. Water Res. 2005, 39, 1099-1104. [CrossRef] [PubMed]

87. Li, Z.; Roy, S.J.; Zou, Y.; Bowman, R.S. Long-term chemical and biological stability of surfactant-modified zeolite. Environ. Sci. Technol. 1998, 32, 2628-2632. [CrossRef]

88. Warchol, J.; Misaelides, P.; Petrus, R.; Zamboulis, D. Preparation and application of organo-modified zeolitic material in the removal of chromates and iodides. J. Hazard. Mater. 2006, 137, 1410-1416. [CrossRef] [PubMed]

89. Campos, V.; Morais, L.C.; Buchler, P.M. Removal of chromate from aqueous solution using treated natural zeolite. Environ. Geol. 2007, 52, 1521-1525. [CrossRef]

90. Zeng, Y.; Woo, H.; Lee, G.; Park, J. Adsorption of Cr(VI) on hexadecylpyridinium bromide (HDPB) modified natural zeolites. Microporous Mesoporous Mater. 2010, 130, 83-91. [CrossRef]

91. Zeng, Y.; Woo, H.; Lee, G.; Park, J. Removal of chromate from water using surfactant modified pohang clinoptilolite and haruna chabazite. Desalination 2010, 257, 102-109. [CrossRef] 
92. Yusof, A.M.; Malek, N.A.N.N. Removal of $\mathrm{Cr}(\mathrm{VI})$ and $\mathrm{As}(\mathrm{V})$ from aqueous solutions by HDTMA-modified zeolite Y. J. Hazard. Mater. 2009, 162, 1019-1024. [CrossRef] [PubMed]

93. Syafalni, R.A.; Nair, P.U. New approach of heavy metal (chromium, iron, copper and nickel) removal using surfactant modified zeolite for tin mining wastewater. World Appl. Sci. J. 2013, 27, 614-620.

94. Noroozifar, M.; Khorasani-Motlagh, M.; Gorgij, M.N.; Naderpour, H.R. Adsorption behavior of Cr(VI) on modified natural zeolite by a new bolaform $N, N, N, N^{\prime}, N^{\prime}, N^{\prime}$-hexamethyl-1,9-nonanediammonium dibromide reagent. J. Hazard. Mater. 2008, 155, 566-571. [CrossRef] [PubMed]

95. Sayed, A.S. Removal of toxic pollutants from aqueous solutions by adsorption onto organo-kaolin. Carbon Lett. 2009, 10, 305-313. [CrossRef]

96. Krishna, B.S.; Murty, D.S.R.; Jai Prakash, B.S. Thermodynamics of chromium(VI) anionic species sorption onto surfactant-modified montmorillonite clay. J. Colloid Interface Sci. 2000, 229, 230-236. [CrossRef] [PubMed]

97. Li, Z.; Beachner, R.; McManama, Z.; Hanlie, H. Sorption of arsenic by surfactant-modified zeolite and kaolinite. Microporous Mesoporous Mater. 2007, 105, 291-297. [CrossRef]

98. Brum, M.C.; Capitaneo, J.L.; Oliveira, J.F. Removal of hexavalent chromium from water by adsorption onto surfactant modified montmorillonite. Miner. Eng. 2010, 23, 270-272. [CrossRef]

99. Li, Z.; Willms, C.A.; Kniola, K. Removal of anionic contaminants using surfactant-modified palygorskite and sepiolite. Clays Clay Miner. 2003, 51, 445-451. [CrossRef]

100. Atia, A.A. Adsorption of chromate and molybdate by cetylpyridinium bentonite. Appl. Clay Sci. 2008, 41, 73-84. [CrossRef]

101. Sheng, G.; Boyd, S.A.; Xu, S. A dual function organoclay sorbent for lead and chlorobenzene. Soil Sci. Soc. Am. J. 1999, 63, 73-78. [CrossRef]

102. Díaz-Blancas, V.; Medina, D.; Padilla-Ortega, E.; Bortolini-Zavala, R.; Olvera-Romero, M.; Luna-Bárcenas, G. Nanoemulsion formulations of fungicide tebuconazole for agricultural applications. Molecules 2016, 21, 1271. [CrossRef] [PubMed]

103. Holland, P.M.; Rubingh, D.N. Mixed surfactant systems. In Mixed Surfactant Systems; American Chemical Society: Washington, DC, USA, 1992; Volume 501, pp. 2-30.

104. Zhao, G.-X.; Xiao, J.-X. Rheological properties of the aqueous mixtures of cationic-anionic surfactants. Colloid Polym. Sci. 1995, 273, 1088-1094. [CrossRef]

105. Somasundaran, P.; Huang, L. Adsorption behavior of surfactant mixtures at solid-liquid interface. Pol. J. Chem. 1997, 71, 568-582.

106. Kume, G.; Gallotti, M.; Nunes, G. Review on anionic/cationic surfactant mixtures. J. Surf. Deterg. 2008, 11, 1-11. [CrossRef]

107. Kovalchuk, N.M.; Barton, A.; Trybala, A.; Starov, V. Surfactant enhanced spreading: Catanionic mixture. Colloids Interface Sci. Commun. 2014, 1, 1-5. [CrossRef]

108. Hao, L.-S.; Yang, N.; Xu, G.-Y.; Jia, Y.-F.; Liu, Q.; Nan, Y.-Q. Specific ion effects on the micellization of aqueous mixed cationic/anionic surfactant systems with various counterions. Colloids Surf. A Physicochem. Eng. Asp. 2016, 504, 161-173. [CrossRef]

(c) 2017 by the authors. Licensee MDPI, Basel, Switzerland. This article is an open access article distributed under the terms and conditions of the Creative Commons Attribution (CC BY) license (http:/ / creativecommons.org/licenses/by/4.0/). 